International Journal of Current Advanced Research

ISSN: O: 2319-6475, ISSN: P: 2319 - 6505, Impact Factor: SJIF: 5.995

Available Online at www.journalijcar.org

Volume 6; Issue 3; March 2017; Page No. 2694-2696

DOI: http://dx.doi.org/10.24327/ijcar.2017.2696.0079

Research Article

\title{
EFFECT OF LEMONGRASS OIL ON RHEUMATOID ARTHRITIS
}

\author{
Priyadharshini.M and R.Gayatri Devi
}

Saveetha Dental College and Hospitals, Chennai 600007.

\begin{tabular}{l}
\hline A R T I C L E I N F O \\
Article History: \\
Received $8^{\text {th }}$ December, 2016 \\
Received in revised form $11^{\text {th }}$ January, 2017 \\
Accepted $6^{\text {th }}$ February, 2017 \\
Published online $28^{\text {th }}$ March, 2017 \\
\hline
\end{tabular}

Key words:

Anti- inflammatory activity, lemongrass oil, pain scale, muscle spasms.

\begin{abstract}
A B S T R A C T
Aim: To do a research on the effect of lemongrass oil on muscle spasms.

Methods: A total of 30 participants who were suffering from muscle spasms were chosen. They were given lemongrass oil to apply for about 30 days. The pain scale was noted once in five days.

Results: The result showed a moderate changes in the pain levels of the patient. Further application would significantly show a greater decrease in the pain levels of the patient.

Conclusion:Muscle spasms being more common in old people, this study was conducted to create awareness about the effect of lemongrass oil on the same.
\end{abstract}

Copyright $@ 2017$ Priyadharshini.M and R.Gayatri Devi. This is an open access article distributed under the Creative Commons Attribution License, which permits unrestricted use, distribution, and reproduction in any medium, provided the original work is properly cited.

\section{INTRODUCTION}

Lemongrass (Cymbopogon) is a tall perennial plant from the Graminieae family, which thrives in tropical and subtropical regions.Lemongrass oil is extracted through the process of steam distillation from the dried leaves of the plant. It has a thin consistency, and a pale or bright yellow color. It has a strong, fresh, lemony, and earthy scent. Lemongrass oil can help relax and tone the muscles, as well as relieve muscle pain, rheumatism.

The main compounds of lemongrass oil are geranyl acetate, myrcene, nerol, citronellal, terpineol, methyl heptenone, dipentene, geraniol, neral, farnesol, limonene, and citral.

Another beneficial compound in lemongrass is limonene, which helps reduce inflammation and kill bacteria, according to research. According to a 2005 study by Dr. Sue Chao, lemongrass oil is one of the top six essential oils with antiinflammatory properties. [1]

Muscle spasms are involuntary, generally painful contractions of a muscle or muscle group,[12] When the motor system is stressed,either by a neuromuscular disease or by a physiologic stress such as dehydration or excessive exercise,cramps become more frequent. Muscle cramps are caused by ectopic discharges from nerves or nerve terminals.[13] Cramps are also frequent during the last trimester of pregnancy and in athletes such as marathon runners Aromatic and medicinal plants are still a major part of traditional medicine in the developing countries.

*Corresponding author: Priyadharshini.M,

Saveetha Dental College and Hospitals, Chennai 600007.
Numerous herbal therapies are currently widely used in medicine.The use of medicinal herbs as anti-inflammatory, antifungal, and analgesic drugs is common in all the countries. [3] Biological research has shown that the various chemical compounds in essential oil possess antibacterial, antifungal, analgesic, and mosquito repellent properties.It is consequently essential to investigate the chemical composition of lemon grass essential oil and evaluate the therapeutic potential of its volatile components. The chemical composition and pharmacological evaluation of lemon grass oil has been the subject of several studies over the years. [2]

\section{MATERIALS AND METHODS}

The pure essential lemongrass oil was commercially bought. A total of 30 patients suffering from muscle spasms were chosen. They belonged to different age groups varying from 35 to 60 . They were given lemongrass oil of about $3 \mathrm{ml}$ for each person and asked to apply for about 30 days. The people applying oil occasionally for muscle spasms are asked to stop that while applying the lemon grass oil. The pain scale was noted once in 5 days. The pain scale considered in this study was from 1-6, 1 being the lowest or no pain and 6 being the severe pain. A table was prepared for the days and the pain scale noted. Accordingly a graph was also drawn.

\begin{tabular}{cc}
\hline Pain scale no. & Mode of pain \\
\hline 1 & No pain \\
2 & Very mild pain \\
3 & Mild pain \\
4 & Moderate pain \\
5 & Severe pain \\
6 & Very severe pain \\
\hline
\end{tabular}




\section{RESULTS}

The effect of lemongrass oil on muscle spasms was noted after 30 days of application. The pain scale showed a significant decrease in the pain levels. The pain levels had decreased gradually. Any application of oil, will not give the result immediately. Similarly, the lemongrass oil showed a very gradual decrease in the pain levels of patients suffering from muscle spasms. In terms of pain scale, on an average, the pain scale before the treatment was at 6 and after the treatment, it got gradually decreased to 3 . In terms of percentage, the pain levels got decreased from $80 \%$ to $50 \%$ approximately.

Table 1 shows the patients whose the pain scale were very severe and the subsequent changes in pain scale. Table 2 shows the patients who decreased from the severe levels of pain scale to moderate levels. Table 3 shows the patients whose pain scale showed a mild changes in some people leading to mild pain.

\section{Table 1}

\begin{tabular}{cc}
\hline Level of pain & Once in 5days \\
\hline Very severe & 19 \\
Severe & 6 \\
Moderate & 5 \\
Mild & 0 \\
Very mild & 0 \\
No pain & 0 \\
\hline & Table 2 \\
\hline Level of pain & \\
\hline Very severe & Once in 10 days \\
Severe & 10 \\
Moderate & 9 \\
Very mild & 5 \\
Mild & 4 \\
No pain & 2 \\
\hline
\end{tabular}

Once in 5 days

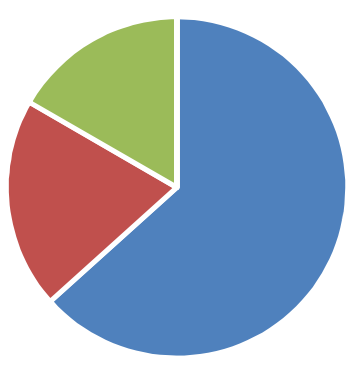

- Very severe - $\quad$ Severe Moderate

- Mild $\quad$ Very mild No pain

Grabh 1

Table 3

\begin{tabular}{cc}
\hline Level of pain & Once in 15 days \\
\hline Very severe & 4 \\
Severe & 7 \\
Moderate & 9 \\
Mild & 7 \\
Very mild & 3 \\
No pain & 0 \\
\hline
\end{tabular}

Once in 10 days

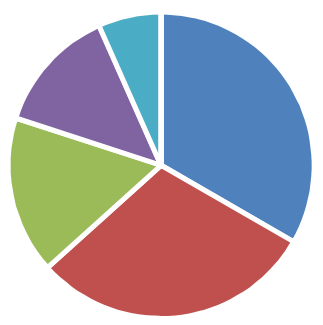

$$
\begin{aligned}
& \text { - Very severe } \quad \text { Severe } \quad \text { - Moderate } \\
& \text { = Mild } \quad \text { Very mild } \quad \text { No pain }
\end{aligned}
$$

Graph 2

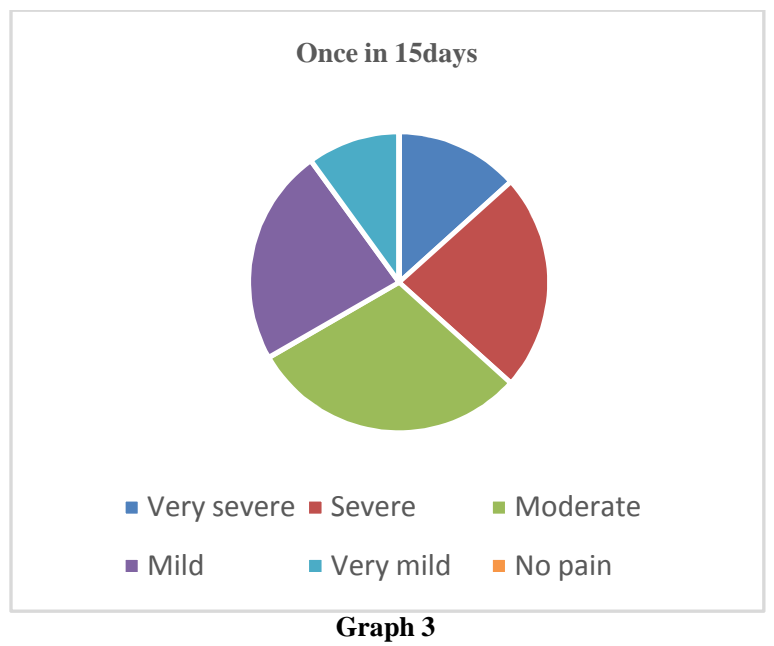

\section{DISCUSSION}

Over the years, essential oils have attracted much attention in scientific research and are increasingly used in pharmaceutical, nutritional and cosmetic industrial applications, primarily due to their potent anti-microbial, antioxidant, anticancer and anti-inflammatory activities of essential oils.[7]

The studies reveal that citral, an chemical constituent present in lemongrass essential oil exhibits greater anti-inflammatory activity. [5,7]

Modern aromatherapy for allergic and inflammatory diseases has been developed primarily based on clinical trials of EOs by several pioneers; however, scientific research on the physiological role of these EOs against allergic and inflammatory responses is still at a primitive stage. The elucidation of the pharmacological functions of lemongrass EO in vivo may provide a rationale for the clinical application of this EO as an anti-allergic and anti-inflammatory substance. [4]

The muscle spasms being very common among the people, this study was done to find the effect of lemon grass oil on the same. The present study reveals that the pain levels of the patient has got gradually decreased during the application of lemongrass oil. So it has shown a positive result about the effect of lemongrass oil on muscle spasms. 


\section{CONCLUSION}

As a staple in modern and ancient natural medicine, lemon grass has proven itself to be a versatile and effective treatment for many ailments. It is a wonderful herb that will provide many health benefits. The ability of this herb to alleviatemuscle can be heightened by using it in a smoothie or $\begin{array}{llll}\text { elixir after a } & \text { arkout. }\end{array}$

\section{References}

1. Mohamed Nadjib Boukhatem, Mohamed Amine Ferhat, Abdelkrim Kameli, Fairouz Saidi, and Hadjer Tchoketch Kebir. Lemongrass (Cymbopogan citratus) essential oil as a potent anti-inflammatory and antifungal drugs.

2. Gagan Shah, Richa Shri, Vivek Panchal, Narender Sharma, Bharpur Singh, and A. S. Mann. Scientific basis for the therapeutic use of Cymbopogam citrates (lemon grass) stalk. J Adv Pharm Technol Res. 2011 Jan-Mar; 2(1): 3-8.

3. Tajidin, N. E.1, Ahmad, S. H1 *, Rosenani, A. B.2, Azimah, H.1 and Munirah. Chemical composition and citral content in lemongrass (Cymbopogan citratus) essential oil at three maturity stages. African Journal of Biotechnology Vol. 11(11), pp. 26852693, 7 February, 2012.

4. Mai Mitoshi, Isoko Kuriyama, Hiroto Nakayam, Hironari Miyazato, Keiichiro SugimotoYuko Kobayashi, Tomoko JippoKouji Kuramochi Hiromi Yoshida Yoshiyuki Mizushina. Suppression of allergic and inflammatory responses by essential oils derived from herbal plants and dry fruits. Ijmm. Monday, March 31, 2014. 1643-1641.

5. Rita de Cassia da Silveira e Sa, Luciana Nalone Andrade and Damiano Pergentino de Sous a. A review on anti-inflammatory activity of Monoterpenes. Molecules 2013, 18(1), 1227-1254.
6. Sirikanokvilai $P$, Kriengsinyos W, Nantiruj k, Muangnoi C, Chingsuwanroj P, Praengam K, Tuntipopipat S. Anti-inflammatory activities of digested green curry paste in peripheral blood mononuclear cells from rheumatoid arthritis patients. Malaysian Journal of Nutrition. Vol 20. Issue 2. 2014.

7. Olorunnisola S.K, Asiyanbi H.T, Hammed A.M, Simsek S. Biological properties of lemongrass: An overview. International Food Research Journal. Vol 21. Issue 2. 2014, p 455-462.

8. Suthagar Pillai Piaru, Shanmugapriya Perumal, Lee Wei Cai, Roziahanim Mahmud, Amin Malik Shah Abdul Majid, Sabariah Ismail. Chemical composition, anti-angiogenic and cytotoxicity activities of the essential oils of Cymbopogan citratus (lemon grass) against colorectal and breast carcinoma cell lines. Pages 453-459. 13 Aug 2012.

9. P Ravi Prakash, NG Ragavendra Rao, Chowdary Soujanya. Formulation, Evaluation and Anti inflammatory activity of Topical etoricoxib gel. Asian Journal of pharmaceutical and Clinical Research. Vol.3 Issue 2, April-June 2010.

10. Louis Kuoping Chao, Kuo-Feng Hua, Hsien-Yeh Hsu, Sen-Sung Cheng, Ju -Yun Liu and Shang Tzen chang. Study on the Anti inflammatory activity of essential oil from the leabes of Cinnamomum osmophloeum. J. Agric. Food Chem., 2005, 53 (18), pp 7274-7278.

11. Learnmore: http://www.naturalnews.com/033587_le mon_grass_muscle_cramps.html\#ixzz4YjqMW7dy

12. Abdulla AJ, Jones P, Pearce V, Leg Cramps in the elderly: Prevalance drug and diseases association. Int J Clin Practice 1999; 53:494-496.

13. Layperson RB.The origin of muscle fasciculations and cramps. Muscle nerve 1994; 17:1243-1249.

Please cite this article in press as:

Priyadharshini.M and R.Gayatri Devi (2017), Effect Of Lemongrass Oil On Rheumatoid Arthritis, International Journal of Current Advanced Research, 6(3), pp. 2694-2696. http://dx.doi.org/10.24327/ijcar.2017. 2696.0079 